\title{
STRATEGI PENGEMBANGAN PADI ORGANIK (Studi Kasus pada Kelompok Tani Putra Mandiri di Desa Linggaraja Kecamatan Sukaraja Kabupaten Tasikmalaya)
}

\author{
VIRGA $^{{ }^{*}}$, SUDRAJAT ${ }^{1}$, BUDI SETIA $^{1}$ \\ ${ }^{1}$ Fakultas Pertanian Universitas Galuh \\ Email : virgagumilar@gmail.com
}

\begin{abstract}
ABSTRAK
Penelitian ini bertujuan untuk mengetahui : (1) Faktor internal dan eksternal yang dapat mempengaruhi pengembangan padi organik pada Kelompok Tani "Putra Mandiri" di Desa Linggaraja Kecamatan Sukaraja Kabupaten Tasikmalaya, (2) Alternatif strategi yang diterapkan dalam pengembangan padi organik pada kelompok tani "Putra Mandiri" di Desa Linggaraja Kecamatan Sukaraja Kabupaten Tasikmalaya. Jenis penelitian yang digunakan dalam penelitian ini adalah metode studi kasus, dengan mengambil kasus pada Kelompok Tani Putra Mandiri di Desa Linggaraja Kecamatan Sukaraja Kabupaten Tasikmalaya. Hasil penelitian menunjukkan, (1) Faktor internal dan eksternal : (a) Faktor-faktor yang menjadi kekuatan dalam pengembangan padi organik yaitu tersedianya cukup jumlah tenaga kerja, kualitas aman, harga menjanjikan, luas lahan budidaya dan memiliki pelanggan atau pembeli tetap, (b) Faktor-faktor yang menjadi kelemahan dalam padi organik yaitu permodalan terbatas, menggunakan teknologi sederhana, kualitas SDM yang masih kurang, promosi masih kurang, Rendahnya Pemasaran di Lingkungan Masyarakat Lokal dan Kurang informasi dari instansi terkait, (c) Faktor-faktor yang menjadi peluang dalam pengembangan padi organik yaitu pangsa pasar luas, permintaan meningkat, harga yang baik di pasaran, pemasaran bisa dilakukan secara online dan kemajuan dan inovasi teknologi, (d.) Faktor-faktor yang menjadi ancaman dalam pengembangan padi organik yaitu pesaing produk sejenis di satu daerah, hama, penyakit dan di pengaruhi cuaca dan iklim. (2) Alternatif strategi yang dapat diterapkan dalam pengembangan padi organik di Desa Linggaraja Kecamatan Sukaraja Kabupaten Tasikmalaya, (a) Mempertahankan kualitas produksi dan pengembangan pasar, (b) Mempertahankan kontinyuitas produksi untuk memenuhi permintaan, (c) Meningkatkan pemasaran di bagian online, (d) Perluas jaringan pasar, (e)perluas jaringan pasar, (f) Optimalisasi penggunaan sarana produksi dengan modal tersedia, (g) Pelatihan bagi SDM untuk meningkatkan keterampilan serta memiliki kemampuan kinerja yang berkualitas (h) pemberantasan hama dan penyakit secara kontinyu, (i) keseragaman harga jual dengan peran serta pengawasan pemerintah (j) menjalin kerja sama dengan pihak terkait dalam menyikapi permodalan, $(\mathrm{k})$ membuat hama dan penyakit tidak menyerang
\end{abstract}

Kata Kunci : Alternatif, Padi Organik, Strategi Pengembangan

\section{ABSTRACT}

This study aimed to find out: (1) Internal and external factors that can affect the development of organic rice in the "Putra Mandiri" group in Linggaraja Village, Sukaraja District, Tasikmalaya Regency, (2) Alternative strategies applied in developing organic rice for "Putra Mandiri" in Linggaraja Village, Sukaraja District, Tasikmalaya Regency. The type of research used in this study is the case study method, by taking the case of Putra Mandiri Farmers Group in Linggaraja Village, Sukaraja District, Tasikmalaya Regency. The results of the study show, (1) Internal and external factors: (a) Factors that become strengths in the development of organic rice are the availability of sufficient number of workers, safe quality, promising prices, area of cultivated land and having regular customers or buyers, (b) Factors the weaknesses in organic rice are limited capital, using simple technology, the quality of human resources is still lacking, promotion is still lacking, low marketing in the local community environment and lack of information from relevant agencies, $(c)$ Factors that become opportunities in developing organic rice i.e. broad market share, increasing demand, good prices on the market, marketing can be done online and technological advances and innovations, (d) Factors that pose a threat in the development of organic rice are competitors of similar products in one area, pests, diseases and influenced by weather and climate. (2) Alternative 
strategies that can be applied in the development of organic rice in Linggaraja Village, Sukaraja District, Tasikmalaya Regency, (a) Maintaining the quality of production and market development, (b) Maintaining production continuity to meet demand, (c) Increasing marketing in the online section, $(d)$ Expanding market networks, (e) expanding market networks, (f) Optimizing the use of production facilities with available capital, $(g)$ Training for human resources to improve skills and have quality performance capabilities (h) continuous eradication of pests and diseases, $(i)$ uniformity of selling prices with the role of government supervision ( $j$ ) establishing cooperation with related parties in addressing capital, (k) making pests and diseases not attack

Keywords: Alternative, Development Strategy, Organic Rice

\section{PENDAHULUAN}

Di Indonesia, pertanian organik semakin menemukan momentumnya seiring munculnya krisis ekonomi tahun 1997 yang melambungkan harga saprotan (sarana produksi pertanian) seperti pupuk kimia dan pestisida kimia. Dengan harga saprotan yang mahal tentu saja menyebabkan tingkat keuntungan menurun. Padahal di lain pihak biaya tenaga kerjanya pun terkadang naik. Inilah yang menyebabkan petani berpaling pada pertanian organik dengan hanya memanfaatkan bahan-bahan disekitarnya (Andoko, 2002).

Kabupaten Tasikmalaya merupakan salah satu Kabupaten di Jawa Barat yang ikut serta dalam pengembangan padi organik untuk meningkatkan penyerapan sektor ekspor dalam negeri. Menurut Dinas Pertanian Kabupaten Tasikmalaya (2017) menyatakan bahwa sebagian besar Kecamatan di Kabupaten Tasikmalaya melaksanakan usahatani padi organik, terlihat dari data luas panen 2.222,26 ha dengan produksi sebesar $16.609,17$ ton menghasilkan produktivitas rata-rata mencapai 7,47 ton/ha. Upaya pihak pemerintah Kabupaten Tasikmalaya yang terus mengembangkan perluasan lahan sawah baru dan pengalihan penanaman padi konvensional ke padi organik untuk memenuhi target permintaan pasar nasional menjadikan Kabupaten Tasikmalaya sebagai salah satu produsen padi organik di Jawa Barat.

Kecamatan Sukaraja merupakan Kecamatan dengan jumlah luas tanam padi organik seluas $30 \mathrm{Ha}$ yang tersebar di 3 desa. Sedikitnya luas areal tanam padi organik tidak menjadi hambatan untuk tetap menjalankan sistem tanam secara organik karena sistem tanam organik sangat menguntungkan apabila dilaksanakan secara efektif.

Berjalannya Kelompok Tani organik di Kecamatan Sukaraja dapat terlihat dari produksi padi organik sebanyak 200,43 ton menghasilkan produktivitas yang cukup tinggi yaitu 7,86 ton/hektar. Dengan hasil produksi yang tinggi dapat memacu 
Kelompok Tani agar lebih intensif melaksanakan sistem tanam padi organik.

Kegiatan Kelompok Tani padi organik di Kecamatan Sukaraja tersebar di 3 desa. Adapun Kelompok Tani yang melaksanakan sistem tanam padi organik di Kecamatan Sukaraja dapat dilihat pada Tabel 2.

Kelompok Tani Padi Organik Di Kecamatan Sukaraja Tahun 2017

\begin{tabular}{cllc}
\hline No & Nama Desa & $\begin{array}{c}\text { Nama } \\
\text { Kelompok }\end{array}$ & $\begin{array}{c}\text { Luas } \\
\text { Lahan } \\
\text { (Ha) }\end{array}$ \\
\hline 1 & Leuwibudah & Karya Tani & 6 \\
2 & Tarunajaya & Balukbuk & 4 \\
3 & Linggaraja & Putra Mandiri & 20 \\
\hline \multicolumn{3}{c}{ Jumlah } & $\mathbf{3 0}$
\end{tabular}

Sumber : BP3K Kecamatan Sukaraja, 2017

Menunjukkan bahwa 3 Kelompok Tani di 3 desa yang berbeda yang melaksanakan sistem tanam padi organik yaitu Kelompok Tani Karya Tani dengan luas 6 Ha di Desa Leuwibudah, Kelompok Tani Balukbuk dengan luas 4 Ha di Desa Tarunajaya, dan Kelompok Tani Putra Mandiri yang memiliki areal tanam paling luas yaitu 20 Ha di Desa Linggaraja.

Kelompok Tani "Putra Mandiri” yang ada di Desa Linggaraja ini sampai saat ini belum melakukan analisis strategi pengembangan padi organik yang diusahakannya, yang berpengaruh dalam menjaga daya saing atau eksistensi petani dan mengatasi masalah-masalah yang ada pada kelompoknya.

Penelitan ini dimaksudkan untuk mencapai tujuan berikut :

1) Faktor internal dan eksternal yang dapat mempengaruhi pengembangan padi organik pada kelompok tani "Putra Mandiri" di Desa Linggaraja Kecamatan Sukaraja Kabupaten Tasikmalaya.

2) Alternatif strategi yang diterapkan dalam pengembangan padi organik pada kelompok tani "Putra Mandiri" di Desa Linggaraja Kecamatan Sukaraja Kabupaten Tasikmalaya.

\section{METODE PENELITIAN}

Jenis penelitian yang digunakan dalam penelitian ini adalah metode studi kasus, dengan mengambil kasus pada kelompok tani "Putra Mandiri" di Desa Linggaraja Kecamatan Sukaraja Kabupaten Tasikmalaya. Menurut Nazir (2011), studi kasus merupakan suatu penelitian yang bersifat mendalam mengenai suatu karakteristik tertentu dari objek penelitian.

\section{Pengumpulan Data}

Data primer dalam penelitian ini diperoleh dengan menggunakan teknik pengumpulan data sebagai berikut : 
1) Pengumpulan Data Melalui Wawancara

2) Pengumpulan Data Melalui Daftar Pertanyaan (Kuesioner)

3) Pengumpulan Data Melalui Observasi Data yang dikumpulkan meliputi data primer dan data sekunder. Data primer ialah data yang diperoleh secara langsung dari kelompok tani Putra Mandiri yang dijadikan responden melalui wawancara, sedangkan data sekunder adalah data yang diperoleh dari literatur-literatur dan data dari instansi atau dinas terkait yang ada hubungannya dengan penelitian ini (Fatoni, 2006).

\section{Penarikan Responden}

Penarikan sampel dalam penelitian ini dilakukan secara purposive sampling yaitu penentuan sampel dengan tujuan tertentu. Jumlah petani yang dijadikan sampel sebanyak 30 petani yang melaksanakan usahatani padi organik di Kelompok Tani Putra Mandiri Desa Linggaraja Kecamatan Sukaraja serta 1 orang pabrik penggiling padi.

\section{Analisis Data}

1) Analisis Faktor Internal dan Faktor Eksternal

Analisis faktor internal bertujuan untuk mengidentifikasi faktor-faktor internal kunci yang menjadi kekuatan dan kelemahan di dalam pengembangan Padi Organik. Faktor internal yang dianalisis meliputi produksi, sumber daya manusia, manajemen, keuangan dan pemasaran. Analisis faktor eksternal bertujuan untuk mengidentifikasi faktor-faktor eksternal kunci yang menjadi peluang dan ancaman bagi pengembangan Padi Organik. Faktor eksternal yang dianalisis meliputi kondisi perekonomian, pemerintah, sosial budaya, teknologi, pemasok dan konsumen serta pesaing.

Untuk mengidentifikasi kekuatan dan kelemahan dari faktor internal serta peluang dan ancaman dari faktor eksternal dalam mengembangkan kelompok tani padi organik "Putra Mandiri" di Desa Linggaraja Kecamatan Sukaraja Kabupaten Tasikmalaya digunakan analisis SWOT. Analisis SWOT adalah identifikasi berbagai faktor secara sistematis untuk merumuskan strategi pengembangan Padi Organik. Analisis ini didasarkan pada logika yang dapat memaksimalkan kekuatan (strengths) dan peluang (opportunities), namun secara bersamaan dapat meminimalkan kelemahan (weaknesses) dan ancaman (threats).

2) Alternatif Strategi

Untuk merumuskan alternatif strategi pengembangan kelompok tani padi 
organik di Desa Linggaraja Kecamatan Sukaraja Kabupaten Tasikmalaya digunakan analisis Matriks SWOT. Analisis SWOT digambarkan ke dalam Matriks SWOT dengan 4 kemungkinan alternatif strategi, yaitu stategi kekuatanpeluang $\quad(S-O \quad$ strategies $), \quad$ strategi kelemahan-peluang (W-O strategies $)$, strategi kekuatan-ancaman ( $S$-T strategies), dan strategi kelemahan-ancaman ( $W-T$ strategies).

Delapan tahapan dalam penentuan alternatif strategi yang dibangun melalui matriks SWOT adalah sebagai berikut :.

(a) Menuliskan peluang faktor eksternal kunci dalam Pengembangan Padi Organik.

(b) Menuliskan ancaman faktor eksternal kunci dalam Pengembangan Padi Organik.

(c) Menuliskan kekuatan faktor internal kunci dalam Pengembangan Padi Organik.

(d) Menuliskan kelemahan faktor internal kunci dalam Pengembangan Padi Organik.

(e) Mencocokkan kekuataan faktor internal dengan peluang faktor eksternal dan mencatat Strategi S-O dalam sel yang sudah ditentukan.

(f) Mencocokkan kelemahan faktor internal dengan peluang faktor eksternal dan mencatat Strategi W-O dalam sel yang sudah ditentukan.

(g) Mencocokkan kekuatan faktor internal dengan ancaman faktor eksternal dan mencatat Strategi S-T dalam sel yang sudah ditentukan.

\section{HASIL DAN PEMBAHASAN}

Identifikasi Faktor Internal dan Eksternal

\section{Faktor Internal}

Faktor internal merupakan faktor yang berasal dari dalam kelompok tani dan dapat dikendalikan. Faktor internal bisa menjadi kekuatan dan kelemahan dalam keberlangsungan kelompok tani padi organik. Adapun faktor-faktor internal adalah sebagai berikut :

a). Sumber Daya Manusia (SDM) adalah potensi yang terkandung dalam diri manusia untuk mewujudkan perannya sebagai makhluk sosial yang adaptif dan transformatif yang mampu mengelola dirinya sendiri serta seluruh potensi yang terkandung di alam menuju tercapainya kesejahteraan kehidupan dalam tatanan yang seimbang dan berkelanjutan.

b). Kondisi Keuangan adalah kondisi kekayaan dimana kelompok tani Putra Mandiri mempunyai perincian 
pendapatan dari perhitungan pengeluaran dan penerimaan.

c). Produksi adalah suatu kegiatan dalam penanaman padi organik yang dikerjakan untuk menambah nilai guna suatu produk sehingga lebih bermanfaat dalam memenuhi kebutuhan.

d). Pemasaran adalah salah satu kegiatan dalam perekonomian untuk menjual padi organik yang membantu dalam menciptakan nilai ekonomi.

Adapun faktor-faktor yang menjadi kekuatan dalam pengembangan padi organik pada Kelompok Tani Putra Mandiri di Desa Linggaraja Kecamatan Sukaraja Kabupaten Tasikmalaya adalah sebagai berikut :

\section{a). Tersedia Cukup Tenaga Kerja}

Pada umumnya bisa dikerjakan oleh siapa saja, maka usahatani padi organik dapat dilakukan secara berkelompok, seiring dengan tergerusnya lahan / pengalihan fungsi lahan yang dari petani menjadi buruh, sehingga $35.70 \%$ adalah buruh.

b). Kualitas Aman

Padi organik merupakan padi yang ditanam secara organik sehingga padi ini aman dan sehat dari bahan bahan kimia, yang dimana menggunaan pupuk kompos serta tak menggunakan pestisida bahan kimia yang dapat membahayakan

c). Harga Yang Menjanjikan

Padi organik sangatlah menjanjikan karena harga di pasar yang relatif tinggi dan stabil, harga jual pada padi organik adalah 5.500

d). Luas Lahan Budidaya

Luas lahan budidaya dapat membuat produksi petani banyak sehingga dapat memenuhi kebutuhan para petani

e). Memiliki Pelanggan Atau Pembeli Tetap

Pelanggan merujuk pada pada penggilingan pada, yaitu yang membeli produk tersebut sehingga mempermudah pemasaran

Adapun faktor-faktor yang menjadi kelemahan dalam pengembangan padi organik pada Kelompok Tani Putra Mandiri di Desa Linggaraja Kecamatan Sukaraja Kabupaten Tasikmalaya adalah sebagai berikut :

a). Permodalan Terbatas

Sulitnya suatu usaha berkembang disebabkan oleh keterbatasan dalam permodalan, sehingga usaha yang dijalankan tidak bisa terus dikembangkan lebih besar hanya sebatas mengelola modal yang dimiliki seadanya 
b). Menggunakan Teknologi Masih Sederhana

Adanya pengaruh yang besar antara pengguanaan teknologi dengan hasil pertanian yang lebih baik tentunya harus dioptimalkan mengingat kebutuhan dunia akan produk hasil pertanian yang tidak akan pernah tercukupi

c). Kualitas Sumber Daya Manusia yang Kurang

Rendahnya tingkat pendidikan di kalangan masyarakat menyebabkan ketrampilan dan pengetahuan mereka terbatas sehingga dalam pengolahan tanah juga belum bisa menerapkan cara-cara yang modern (pengolahan dengan mesin), masih dengan cara yang sederhana atau manual.

d). Promosi Masih Kurang

Kurangnya promosi menyebabkan produk sulit dikenal ke luar wilayah.

e). Rendahnya Pemasaran di Lingkungan Masyarakat Lokal

Rendahnya pemasaran di sebagian masyarakat lokal menyebabkan terjadinya produksi di kalangan masyarakat, dimana sebagian orang lebih memilih menanam padi organik sendiri dari pada membelinya

f). Kurang informasi dari instansi terkait
Kurangnya informasi dari pemerintah sehingga tidak adanya informasi yang sampai ke petani, baik informasi dalam hal pengajuan bantuan, informasi harga, promosi dan pemasaran.

\section{Faktor Eksternal}

Faktor eksternal adalah faktorfaktor di luar kelompok tani padi organik dan belum dapat dikendalikan sepenuhnya, faktor ekternal tersebut bisa menjadi peluang dan ancaman dalam keberlangsungan kelompok tani padi organik, adapun faktor-faktor eksternal adalah sebagai berikut :

a. Kondisi Ekonomi adalah keadaan keuangan suatu daerah yang dapat berpengaruh terhadap fluktuasi harga pada padi organik.

b. Sosial Budaya adalah suatu cara hidup yang berkembang dan dimiliki bersama oleh sebuah kelompok orang pada kelompok tani Putra Mandiri.

c. Kebijakan Pemerintah adalah kebijakan-kebijakan yang dibuat oleh pemerintah untuk mencapai tujuantujuan tertentu di masyarakat yang berhubungan dengan pengembangan padi organik.

d. Pelanggan adalah orang yang membeli padi organik.

e. Teknologi adalah keseluruhan sarana untuk menyediakan barang-barang 
yang diperlukan bagi kelangsungan

dan kenyamanan hidup dalam mengelola tanah untuk produksi padi organik.

f. Pesaing adalah petani padi organik yang sama atau produk yang sejenis dan menjual kepada pelanggan.

g. Keadaan alam adalah kondisi alam yang ada yang mempengaruhi padi.

Adapun faktor-faktor yang menjadi peluang dalam pengembangan padi organik di Desa Linggaraja Kecamatan Sukaraja Kabupaten Tasikmalaya adalah sebagai berikut:

a). Pangsa Pasar Luas

Padi organik merupakan produk yang banyak diminati oleh masyarakat, sehingga pangsa pasar padi organik masih luas

b).

$$
\text { Permintaan Meningkat }
$$

Meningkatnya padi organik menyebabkan petani harus ekstra keras agar tingkat produksinya meningkat

c). Harga di pasaran baik

Untuk padi organik harga di pasaran sangat stabil dan relatif tinggi

d).

Pemasaran

Bisa

Dilakukan Secara Online

Pemasaran secara online sekarang bisa dilakukan secara individu, mudah dan praktis, banyak sarana market place yang tersedia dalam melakukan pemasaran secara online, sehingga tidak sulit untuk melakukan penjualan / pemasaran padi organik.

Adapun faktor-faktor yang menjadi ancaman dalam pengembangan padi organik pada Kelompok Tani Putra Mandiri di Desa Linggaraja Kecamatan Sukaraja Kabupaten Tasikmalaya adalah sebagai berikut :

a). Pesaing Produk Sejenis di Satu Daerah Di wiliayah Kecamatan Sukaraja terdapat tiga kelompok tani padi organik namun lahan terluas berada di Desa Linggaraja sehingga tingkat produksi sangatlah besar

b). Hama

Hama menjadi sumber utama dalam ancaman pada para petani karena dapat mengurangi tingkat produksi padi organik

c). Penyakit

Dalam pertanian penyakit adalah suatu gambaran ancaman karena dapat membuat tanaman kerdil

d). Dipengaruhi oleh cuaca dan iklim Untuk pertanian padi organik sangat tergantung pada cuaca dan iklim jadi sangat kesulitan jika terjadi musim kemarau karena kesulitan air.

Setelah faktor-faktor strategi internal dan eksternal diidentifikasi, selanjutnya 
menyusun Tabel IFAS (Internal Strategic

Factors Analysis Summary) dan EFAS (Eksternal Strategic Factors Analysis Summary), Tabel tersebut disusun untuk merumuskan faktor-faktor strategi internal dalam kerangka kekuatan dan kelemahan serta faktor-faktor strategi eksternal dalam kerangka peluang dan ancaman. Untuk lebih jelasnya dapat dilihat :

Tabel IFAS (Internal Strategic Factors Analysis Summary)

\begin{tabular}{|c|c|c|c|}
\hline $\begin{array}{c}\text { Faktor-Faktor Strategi } \\
\text { Internal } \\
\end{array}$ & Bobot & Rating & $\begin{array}{l}\text { Bobot } x \\
\text { Rating }\end{array}$ \\
\hline Kekuatan & & & \\
\hline \multirow{5}{*}{$\begin{array}{l}\text { - Tesedia cukup jumlah } \\
\text { tenaga kerja } \\
\text { - Kualitas aman } \\
\text { - Harga menjanjikan } \\
\text { - Luas lahan budidaya } \\
\text { - Memiliki pelanggan atau } \\
\text { pembeli tetap }\end{array}$} & 0,10 & 2 & 0,20 \\
\hline & 0,10 & 3 & 0,30 \\
\hline & 0,10 & 4 & 0,40 \\
\hline & 0,10 & 4 & 0,80 \\
\hline & 0.10 & 2 & 0.20 \\
\hline \multirow{8}{*}{$\begin{array}{l}\text { Kelemahan } \\
\text { - Permodalan terbatas } \\
\text { - Menggunakan teknologi } \\
\text { - } \text { sederhana } \\
\text { - Kualitas SDM kurang } \\
\text { - Promosi masih kurang } \\
\text { - Rendahnya pemasaran di } \\
\text { lingkungan masyarakat } \\
\text { lokal } \\
\text { - Kurang informasi dari } \\
\text { instansi terkait } \\
\end{array}$} & & & \\
\hline & 0,10 & 1 & 0,20 \\
\hline & 0,05 & 3 & 0,15 \\
\hline & 0,05 & 2 & 0,10 \\
\hline & 0,10 & 2 & 0,20 \\
\hline & 0,10 & 2 & 0,20 \\
\hline & 0,05 & 1 & 0.05 \\
\hline & 0.05 & 1 & 0.05 \\
\hline Total & 1,00 & & 2,85 \\
\hline
\end{tabular}

kekuatan dan kelemahan adalah 2,85. Nilai total ini menggambarkan bahwa kelompok tani padi organik memiliki dukungan faktor internal relatif sedang, selain itu kekuatan yang dimilikilebih tinggi dibandingkan dengan kelemahan.

\begin{tabular}{|c|c|c|c|}
\hline \multirow{2}{*}{$\begin{array}{c}\text { EFAS (Eksternal } \\
\begin{array}{c}\text { Analysis Summary) } \\
\text { Faktor-Faktor Strategi } \\
\text { Eksternal }\end{array}\end{array}$} & \multicolumn{2}{|c|}{ Strategic } & Factors \\
\hline & \multirow{2}{*}{ Bobot } & \multirow{2}{*}{ Rating } & \multirow{2}{*}{$\begin{array}{c}\text { Bobot } x \\
\text { Rating }\end{array}$} \\
\hline \multirow{6}{*}{$\begin{array}{l}\text { Peluang } \\
\text { - Pangsa pasar luas } \\
\text { - Permintaan meningkat } \\
\text { - Harga yang baik di } \\
\text { pasaran } \\
\text { - Pemasaran bisa } \\
\text { dilakukan } \\
\text { secara online } \\
\text { - Kemajuan dan inovasi } \\
\text { teknologi }\end{array}$} & & & \\
\hline & 0,15 & 4 & 0,60 \\
\hline & 0,10 & 3 & 0,30 \\
\hline & 0.10 & 2 & 0,20 \\
\hline & 0.05 & 2 & 0,10 \\
\hline & 0.05 & 1 & 0.05 \\
\hline \multirow{5}{*}{$\begin{array}{l}\text { Ancaman } \\
\text { - pesaing produk sejenis } \\
\text { di satu daerah } \\
\text { - Hama } \\
\text { - Penyakit } \\
\text { - Dipengaruhi cuaca dan } \\
\quad \text { iklim }\end{array}$} & & & \\
\hline & 0,20 & 3 & 0,60 \\
\hline & 0,10 & 2 & 0,20 \\
\hline & 0,10 & 2 & 0,20 \\
\hline & 0,15 & 2 & 0,30 \\
\hline Total & 1,00 & & 2,35 \\
\hline
\end{tabular}

Menunjukkan bahwa total peluang dan ancaman adalah 2,35. Dukungan faktor eksternal juga sedang, selain itu peluang yang dimiliki cukup tinggi dibandingkan dengan ancaman yang mampu mendukung pengembangan kelompok tani Putra Mandiri dalam produksi padi organik

\section{Matrik Internal-Eskternal}

Total skor matrik faktor internal sebesar 2,85 yang menggambarkan bahwa padi organik berada pada kondisi internal sedang. Sedangkan total skor matrik eksternal sebesar 2,35 yang menggambarkan bahwa padi organik pada kondisi sedang. Berdasarkan skor pada kedua matrik faktor internal dan faktor eksternal maka padi organik berada pada sel $\mathrm{V}$ yang artinya usaha tersebut berada dalam kondisi internal dan eksternal sedang.. Alternatif Strategi 
Penentuan alternatif strategi ditentukan dengan menggunakan matrik SWOT. Rangkuti (2009) menjelaskan bahwa Matrik SWOT dapat menggambarkan secara jelas bagaimana peluang dan ancaman eksternal yang dihadapi perusahaan dapat disesuaikan dengan kekuatan dan kelemahan yang dimilikinya. Matrik ini dapat menghasilkan empat set kemungkinan alternatif strategis, sebagaimana dapat dilihat pada Tabel.

\section{Diagram Matrik SWOT}

\begin{tabular}{|c|c|c|}
\hline EFAS & STRENGHTS (S) & WEAKNESSES $(W)$ \\
\hline & $\begin{array}{l}\text { - } \text { Tesedia Cukup } \\
\text { Jumlah Tenaga } \\
\text { Kerja } \\
\text { - } \text { Kualitas aman } \\
\text { - Harga menjanjikan } \\
\text { - Lokasi budidaya } \\
\text { luas } \\
\text { - Memiliki } \\
\text { pelanggan/pembeli } \\
\text { tetap }\end{array}$ & $\begin{array}{l}\text { - } \begin{array}{c}\text { Permodalan } \\
\text { terbatas }\end{array} \\
\text { - Penggunaan } \\
\text { teknologi } \\
\text { masih sederhana } \\
\text { - Kualitas SDM } \\
\text { kurang } \\
\text { - Promosi masih } \\
\text { kurang } \\
\text { - Rendahnya } \\
\text { pemasaran di } \\
\text { lingkungan } \\
\text { masyarakat lokal } \\
\text { - Kurang adanya } \\
\text { peran pemerintah }\end{array}$ \\
\hline $\begin{array}{c}\text { OPPORTUNITIE } \\
(O)\end{array}$ & STRATEGI S-O & STRATEGI W-O \\
\hline $\begin{array}{l}\text { - Pangsa pasar } \\
\text { luas } \\
\text { - Permintaan } \\
\text { menin } \\
\text { gkat } \\
\text { - Harga baik di } \\
\text { pasaran } \\
\text { - Pemasaran bisa } \\
\text { dilakukan } \\
\text { secara online } \\
\text { - Kemajuan dan } \\
\text { inovasi } \\
\text { teknologi }\end{array}$ & $\begin{array}{l}\text { - Mempertahankan } \\
\text { kualitas produksi } \\
\text { dan } \\
\text { pengembangan } \\
\text { pasar } \\
\text { - Mempertahankan } \\
\text { kontinyuitas } \\
\text { produksi untuk } \\
\text { memenuhi } \\
\text { permintaan } \\
\text { - Meningkatkan } \\
\text { pemasaran di } \\
\text { bidang online } \\
\text { - Perluas jaringan } \\
\text { pasar } \\
\end{array}$ & 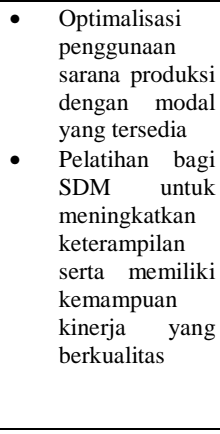 \\
\hline TREATHS $(T)$ & STRATEGI S-T & STRATEGI W-T \\
\hline $\begin{array}{l}\text { - } \text { pesaing produk } \\
\text { sejenis } \\
\text { - Hama } \\
\text { - Penyakit } \\
\text { - Kurang adanya } \\
\text { peran } \\
\text { pemerintah } \\
\text { - Dipengaruhi } \\
\text { cuaca dan iklim }\end{array}$ & \begin{tabular}{ll}
- & \multicolumn{2}{l}{ Pemberantasan } \\
hama dan \\
penyakit & secara \\
kontinyu & \\
- & Keseragaman \\
harga jual & \\
dengan peran \\
serta \\
pengawasan \\
pemerintah
\end{tabular} & $\begin{array}{l}\text { - Menjalin kerja } \\
\text { sama dengan } \\
\text { pihak terkait } \\
\text { dalam } \\
\text { menyikapi } \\
\text { permodalan } \\
\text { Membuat cara } \\
\text { agar hama dan } \\
\text { penyakit tidak } \\
\text { menyerang }\end{array}$ \\
\hline
\end{tabular}

Setelah mengidentifikasi faktorfaktor internal dan eksternal yang menjadi kekuatan dan kelemahan serta peluang dan ancaman dalam mengembangkan padi organik di Desa Linggaraja Kecamatan Sukaraja Kabupaten Tasikmalaya, maka diperoleh beberapa alternatif strategi yang dapat dipertimbangkan, antara lain:

a). Strategi S-O

Strategi Strength-Opportunity (S-O) atau strategi kekuatan peluang adalah strategi yang menggunakan kekuatan internal untuk memanfaatkan peluang eksternal. Alternatif strategi S-O yang dapat dirumuskan adalah :

1) Mempertahankan Kualitas Produksi dan Pengembangan Pasar.

Pasar merupakan tempat untuk mendistribusikan padi organik kepada konsumen. Sehingga mempertahankan kualitas produksi penting untuk dapat terus bersaing dan dalam upaya mengembangkan

pemasaran. Mempertahankan kualitas dapat dilakukan dengan menentukan standarisasi kualitas produk. Pengembangan pasar dilakukan untuk peningkatan volume penjualan dengan menawarkan produk pada pedagang baru di daerah lain yang potensial. Sehingga dapat dijadikan salah satu cara untuk memperluas daerah pemasaran 
dan untuk mendapatkan pelangganpelanggan baru.

2) Mempertahankan kontinuitas produksi untuk memenuhi permintaan

Kontinuitas produksi sangat diperlukan untuk memenuhi permintaan konsumen. Dengan produksi yang terus berlanjut diharapkan mampu mempertahankan pelanggan yang sudah ada bahkan mampu menarik lebih banyak lagi pelanggan atau konsumen lainnya.

3) Meningkatkan pemasaran di bidang online

Penggunaan pasar dengan cara online dilakukan untuk peningkatan volume penjualan dengan menawarkan produk pada pedagang atau konsumen langsung via media sosial / elektronik, sehingga dapat memperluas area pemasaran.

4) Perluas jaringan pasar

Adanya kerjasama dengan beberapa pedagang / penggilingan padi di luar daerah, sehinngga jaringan penjualan luas.

\section{b). Strategi W-O}

Strategi Weakness-Opportunity (W-O) atau strategi kelemahan peluang adalah strategi untuk meminimalkan kelemahan yang ada dengan memanfaatkan peluang eksternal. Alternatif strategi W-O yang dapat dirumuskan adalah :
1) Optimalisasi penggunaan sarana produksi dengan modal yang tersedia Sarana produksi berpengaruh dalam pengambilan keputusan dalam menjalankan pertanian padi organik. Sehingga harus mengoptimalkan sarana produksi agar produk menjadi lebih baik dengan modal seadannya, karena jika sarana produksi sudah baik maka proses produksi pun akan berjalan dengan lancar dan permintaan akan tetap terpenuhi.

2) Pelatihan bagi SDM untuk meningkatkan keterampilan serta memiliki kemampuan kinerja yang berkualitas

Pentingnya pelatihan bagi SDM maka petani dituntut untuk memiliki kemampuan yang baik, oleh karena itu dengan adanya pelatihan tentu saja nantinya petani dapat bekerja menjadi lebih baik dan efektif, kemudian juga untuk meningkatkan kualitas kerja sehingga akan mendapatkan kualitas yang baik serta menghasilkan produk yang berkualitas

c). Strategi S-T

Strategi Strength-Threat (S-T) atau strategi kekuatan-ancaman adalah strategi untuk mengoptimalkan kekuatan internal yang dimiliki dalam menghindari 
ancaman. Alternatif strategi S-T yang dapat dirumuskan adalah :

1) Pemberantasan hama dan penyakit secara kontinyu

Hama dan penyakit pada suatu tanaman sangatlah lumrah, namun dalam penanganan hama dan penyakit ini perlu adannya tindakan secara kontiyu dengan memberikan insektisida alami.

2) Keseragaman Harga Jual dengan Peran Serta Pengawasan Pemerintah Harga jual yang bervariasi terutama pada pedagang pengecer dapat merugikan konsumen. Harga jual tidak dipertimbangkan dengan harga dari produsen. Dalam hal ini perlu pengawasan pemerintah dalam menetukan standar harga jual pedagang pengecer dan berdasarkan dengan kualitas produk. Konsumen dapat menawar apabila harga yang ditawarkan pedagang pengecer terlalu tinggi.

d) Strategi W-T Strategi Weakness-Threat (W-T) atau strategi kelemahan ancaman adalah strategi defensif untuk meminimalkan kelemahan internal dan menghindari ancaman eksternal. Alternatif strategi yang dapat dirumuskan adalah :

1) Menjalin Kerjasama dengan Pihak Terkait dalam Menyikapi Permodalan Menjalin kerjasama dengan pihak terkait seperti masyarakat sekitar, pemerintah Desa Linggaraja, Pengusaha melakukan pertemuan rutin untuk menciptakan iklim usaha yang baik antar berbagai pihak. Upaya yang lain yaitu peani membentuk perkumpulan sesama petani. Sehingga petani dapat mengetahui sejauh mana keberhasilan mengembangkan usahanya.

2)Membuat cara agar hama dan penyakit tidak menyerang

Untuk hama dan penyakit adalah permasalahan yang serius, selain membuat tingkat produksi rendah, hal ini juga dapat membuat tanaman menjadi kerdil dll, sehingga perlu adanya penanganan khusus untuk hama ini yaitu dengan pemberian obat hama secara alami.

\section{KESIMPULAN}

\section{Kesimpulan}

1. Faktor-faktor internal dan eksternal pada pengembangan Padi Organik di Desa Linggaraja, Kecamatan Sukaraja Kabupaten Tasikmalaya antara lain :

a). Kekuatan

Faktor-faktor yang menjadi kekuatan dalam pengembangan padi organik yaitu tersedia cukup jumlah tenaga kerja, Kualitas aman, harga menjajikan dan luas lahan budidaya 
b). Kelemahan

Faktor-faktor yang menjadi kelemahan dalam padi organik yaitu permodalan terbatas, penggunaan teknologi sederhana, kualitas SDM yang masih kurang, promosi masih kurang, rendahnya pemasaran di lingkungan masyarakat lokal dan kurang informasi dari instansi terkait

c). Peluang

Faktor-faktor yang menjadi peluang dalam pengembangan padi organik yaitu area terluas, pangsa pasar luas, permintaan semakin meningkat, harga yang baik di pasaran, pemasaran bisa dilakukan secara online dan memiliki pelanggan atau pembeli tetap

d). Ancaman

Faktor-faktor yang menjadi ancaman dalam pengembangan padi organik yaitu ada pesaing produk sejenis disatu daerah, hama, penyakit dan di pengaruhi cuaca dan iklim.

2. Alternatif strategi yang dapat diterapkan dalam pengembangan padi organik di Desa Linggaraja Kecamatan Sukaraja Kabupaten Tasikmalaya.

a. Mempertahankan kualitas produksi dan pengembangan pasar. b. Mempertahankan kontinuitas produksi untuk memenuhi permintaan

c. Optimalisasi pengguanaan sarana produksi dengan modal seadannya

d. Pelatihan bagi SDM untuk meningkatkan keterampilan serta memiliki kemampuan kinerja yang berkualitas

e. Menjalin kerja sama dengan pihak terkait dalam menyikapi permodalan.

f. Membuat cara agar hama dan penyakit tidak menyerang.

\section{Saran}

1) Penentuan standar kualitas padi organik dan produktifitas agar dapat memenuhi permintaan konsumen. Produk memiliki daya saing dan menjadi sumber penghasilan utama sehingga harus tetap dikembangkan karena petani ini mempunyai prospek yang baik.

2) Sebaiknya pengembangan pasar dilakukan dengan meningkatkan promosi dan dengan membuka pangsa pasar baru untuk mendapatkan pelanggan baru, terutama pelanggan di luar kota.

3) Ketersediaan padi organik sebaiknya lebih terjamin, melalui koordinasi dengan pihak terkait, pemasok, 
pemerintah dan pedagang. Hal tersebut agar padi organik semakin laku di pasaran dan membuat masyarakat mengerti bahwa padi organik merupakan makanan yang sehat dan terhindar dari bahan bahan kimia.

\section{DAFTAR PUSTAKA}

Andoko, A., 2002. Budi Daya Padi Secara Organik. Penebar Swadaya, Jakarta.
BPP Kecamatan Sukaraja Kabupaten Tasikmalaya 2018. Data Kelompok Tani Padi Organik dan Data Curah Hujan Kecamatan Sukaraja Kabupaten Tasikmalaya 2018. Tasikmalaya.

Fatoni. 2006. Organisasi dan Manajemen Sumber Daya Manusia. Rineka Cipta. Jakarta

Dinas Pertanian Kabupaten Tasikmalaya, 2016. Data Padi Organik Kabupaten Tasikmalaya. Tasikmalaya.

Nazir, M. 2011. Metode Penelitian. Ghalia Indonesia. Bogor. 